\title{
INHIBITORY ACTIVITY OF COMPOUNDS ISOLATED FROM POLYMNIA SONCHIFOLIA ON AFLATOXIN PRODUCTION BY ASPERGILLUS FLAVUS
}

\author{
Adriana Pak ; Edlayne Gonçalez ${ }^{2 *}$; Joana D’arc Felicioº ; Marina Mori Pinto²; Maria Helena Rossi²; \\ Isabela Cristina Simoni²; Márcia Nasser Lopes ${ }^{1}$
}

${ }^{1}$ Instituto de Química, Universidade Estadual Paulista, Araraquara, SP, Brasil; ${ }^{2}$ Instituto Biológico, Centro de Sanidade Animal, São Paulo, SP, Brasil

Submitted: June 09, 2005; Returned to authors for corrections: January 06, 2006; Approved: March 30, 2006

\begin{abstract}
Polymnia sonchifolia, commonly known as "yacon", was originally cultivated at Andes moutains in South America. Recently, the specie attracted worldwide attention because of its wide range of uses, for example in the control of diabetes melitus, besides the antifungal and pesticidal compounds were found in the leaves. This study describes the identification of two flavonoids: 3', 5, 7 trihydroxy-3, 4'-dimethoxyflavone (compound 1) and 3', 4', 5- trihydroxy-7-methoxy flavanone (compound 2) and two sesquiterpenes lactones: enhydrin (compound 3) and a mixture of enhydrin and uvedalin (compound 4) isolated from Polymnia sonchifolia leaves and their effects on the aflatoxin production by Aspergillus flavus. The identification of the compounds were achieved by ${ }^{1} \mathrm{H}$ and ${ }^{13} \mathrm{C}$ NMR. All compounds were tested in different concentration, to evaluate the growth of Aspergillus flavus culture and the production of aflatoxin. The compound 1, at the concentration $15 \mu \mathrm{g} / \mathrm{mL}$, inhibited $25 \%$ of the aflatoxin $\mathrm{B}_{1}$ production ( $\mathrm{p}<0.01$ ). The compound 4 inhibited $34 \%$ and $76 \%$ of the fungal growth and $\mathrm{AFB}_{1}$ production respectively. These results show that Polymnia sonchifolia can be used for the development of agents to control aflatoxin $\mathrm{B}_{1}$ production by Aspergillus flavus.
\end{abstract}

Key words: Polymnia sonchifolia, flavonoids, melampolides, aflatoxin, Aspergillus flavus

\section{INTRODUCTION}

Aflatoxins are bifuranocumarin mycotoxins produced by Aspergillus flavus and Aspergillus parasiticus, with aflatoxin $\mathrm{B}_{1}$ $\left(\mathrm{AFB}_{1}\right)$ being the most hepatotoxic, showing mutagenic and carcinogenic and probably teratogenic properties in animals $(15,16)$. According to the International Agency for Research on Cancer, aflatoxins are classified as human carcinogens class 1 (8).

Previous studies have shown that the biosynthesis of aflatoxin $B_{1}$ can be inhibited by a number of compounds (4). Extracts of certain plants are toxic to fungi and may be useful in controlling the fungal growth and mycotoxin production (14). Plant extracts, such as those from garlic and onion, effectively retarded growth and aflatoxin production (5). Natural compounds, such as flavonoids, biflavonoids, stilbenes, essential oils and others, were also active in inhibition of aflatoxin production $(1,7,10,11,13)$.

There is increasing interest in antifungical agents for growth control of mycotoxin producing strains, however, some of the agents may pose toxic residue problems (2).

Inoue 1995 (9) reported the isolation of fungicidal compounds against Pyricularia aryzae from leaves extracts of Polymnia sonchifolia.

Pinto et al. 2001 (12) and Gonçalez et al. 2003 (6) reported the inhibition of aflatoxin production by aqueous and ethanolic extracts from Polymnia sonchifolia when added to Aspergillus flavus culture.

This paper reports the chemical structure identification and the activity of compounds isolated from leaves of the $P$. sonchifolia against Aspergillus flavus.

*Corresponding Author. Mailing address: Instituto Biológico, Centro de Sanidade Animal, Av. Conselheiro Rodrigues Alves, 1252. 04014-002, São Paulo, SP, Brasil. Telefax.: (+5511) 5087-1754. E-mail: goncalez@ biologico.sp.gov.br 


\section{MATERIALS AND METHODS}

\section{Preparation of plant extract}

P. sonchifolia was collected in Capão Bonito City, São Paulo State, Brazil. Dried and powdered leaves were submitted to extraction with ethanol $98 \%$ (three times), at room temperature. The solvent was evaporated under vaccum to yield an ethanolic extract (EE) (6).

\section{Isolation and identification of compounds}

The EE was submitted to flash chromatographic column over Silica-gel, eluted with hexane, ethyl acetate and methanol. The ethyl acetate fraction showed higher activity than the other fractions (6), and was submitted to the chromatografic column on silica gel $60 \mathrm{H}$ eluted with hexane:acetate (3:7, 2:8, 1:9 and $0: 10)$ for the obtention of the subfractions.

These subfractions were tested in Aspergillus flavus culture to verify the inhibitory activity in the production of aflatoxin. The most active subfraction was submitted to the isolation of the constituents by chromatographic column using silica gel $60 \mathrm{H}$ and sephadex LH-20, yielding the compounds: 1, 2, 3 and 4. The structures of the compounds were elucidated by ${ }^{13} \mathrm{C}$ and ${ }^{1} \mathrm{H}$ NMR (HMQC, HMBC, DEPT, NOISE, $\mathrm{H}^{1}{ }^{1}{ }^{1} \mathrm{H}$ COSY) techniques.

\section{Culture conditions}

Aspergillus flavus IMI 190 (International Mycological Institute) was grown on potato dextrose agar (Difco Laboratories, Detroit, Mich) plates for 10 days, at $25^{\circ} \mathrm{C}$, until well sporulated. The spore suspension used as inoculum was prepared washing the cultures with sterile solution of Tween $80(0.01 \%)$. The suspension was submited to spore counting in a Neubauer Chamber.

\section{Aflatoxin production and Aspergillus flavus growth evaluation}

The semi-synthetic Yes culture medium was used for testing aflatoxin production (3). Suspensions contaning $1.3 \times 10^{5}$ spores $/ \mathrm{mL}$ were inoculated into $50 \mathrm{~mL}$ of Yes medium, at different concentration of the subfractions, 0 (control), 25, 50 and $75 \mu \mathrm{g} / \mathrm{mL} ; 0$ (control), 5, 10 and $20 \mu \mathrm{g} / \mathrm{mL}$ for compound 1 ; 0 (control), 10, 20 and $40 \mu \mathrm{g} / \mathrm{mL}$ for compound 2; 0 (control), 4 , 9 and $14 \mu \mathrm{g} / \mathrm{mL}$ for compound 3 and 0 (control), 10, 15 and 20 $\mu \mathrm{g} / \mathrm{mL}$ for compound 4 . Three replicates were performed for each concentration. The production of aflatoxin $B_{1}$ was obtained with cultures incubated at $25^{\circ} \mathrm{C}$ for 5 days. The cultures were then filtered and the dry weight of each mycelium was determined after drying at $50^{\circ} \mathrm{C}$, for 4 days. Aflatoxins were extracted with $25 \mathrm{~mL}$ of chloroform for three times. The extracts were combined, evaporated and the residue was dissolved and made up to $1 \mathrm{~mL}$ in a volumetric flask with chloroform, which was used for analysis.

\section{Aflatoxin analysis}

Samples of $5 \mu \mathrm{L}$ from replicates were spotted on silica gel-G thin layer plate which was developed using chloroform:acetone 9:1 (v/v) as solvent system. Concentrations of the aflatoxin $\mathrm{B}_{1}\left(\mathrm{AFB}_{1}\right)$ were determined by photodensitometry (photodensitimeter Shimadzu, CS 9000), by comparing the area of the spots samples with aflatoxin standards.

\section{Statistical analysis}

The statistical analysis was performed using one way analysis of variance (ANOVA) and Tukey-Kramer multiple comparisons test with significance level $\mathrm{p}<0.05$ and $\mathrm{q}>4.457$.

\section{RESULTS}

Gonçalez et al. 2003 related the inhibitory activity of the ethanolic extract of leaves of $P$. sonchifolia and its fractions (hexane, chloroform, ethyl acetate and methanolic). Chemical study was performed in a biomonitoring assay of the ethyl acetate fraction, yielding the isolation of the active principle.

The hexane:acetate $(3: 7 ; 2: 8 ; 1: 9$ and $0: 10)$ subfractions were tested in Aspergillus flavus culture. The first fraction showed the highest activity of the tested concentrations $(25,50$ and $75 \mu \mathrm{g} / \mathrm{mL}$ ) and $\mathrm{AFB}_{1}$ production was inhibited in $81.3 \%$; $85.4 \%$ and $95.3 \%$, respectively. This subfraction was purified by chromatography, yielding four compounds.

The spectral analyses showed the existence of two different groups of natural compounds. Compounds 1 and 2 showed spectrometric characteristics of flavonoids and compound 3 and 4 were sesquiterpene lactones.

The ${ }^{13} \mathrm{C}$ NMR spectra indicated similar A and B- ring oxigenation patterns for the flavonoids 1 and 2 and differences in the $\mathrm{C}$ ring.

The comparison of the ${ }^{13} \mathrm{C}$ NMR data of compounds 1 and 2 with the data obtained from literature permitted the identification of flavonoids 1 and 2 as 3', 5, 7 trihydroxy-3, 4'-dimethoxyflavone (Fig. 1) and 3', 4', 5- trihydroxy-7-methoxy flavanone (Fig. 2).

Compounds 3 and 4 showed ${ }^{13} \mathrm{C}$ and ${ }^{1} \mathrm{H}$ NMR spectra (NOISE and DEPT) almost identical to two sesquiterpene lactones described in literature (9). Differences between them were observed in the signals which were indicative of an aditional epoxide group in the carbons C-4 and C-5 of compound 3. Compound 4 was a mixture of compound 3 and another compound with one double bond between C-4 and C-5.

Analysis of these results indicated that compound 3 was as enhydrin (Fig. 3) and 4 as a mixture of enhydrin and uvedalin (Fig. 4).

These compounds were tested in Aspergillus flavus culture to evaluate the aflatoxin $\mathrm{B}_{1}\left(\mathrm{AFB}_{1}\right)$ production and the effects on fungus growth. The results are shown in Figs. 1, 2, 3 and 4.

The aflatoxin $\mathrm{B}_{1}$ production was inhibited by compound 1 $(\mathrm{p}<0.05)$, but the compound 2 did not show the same effect 


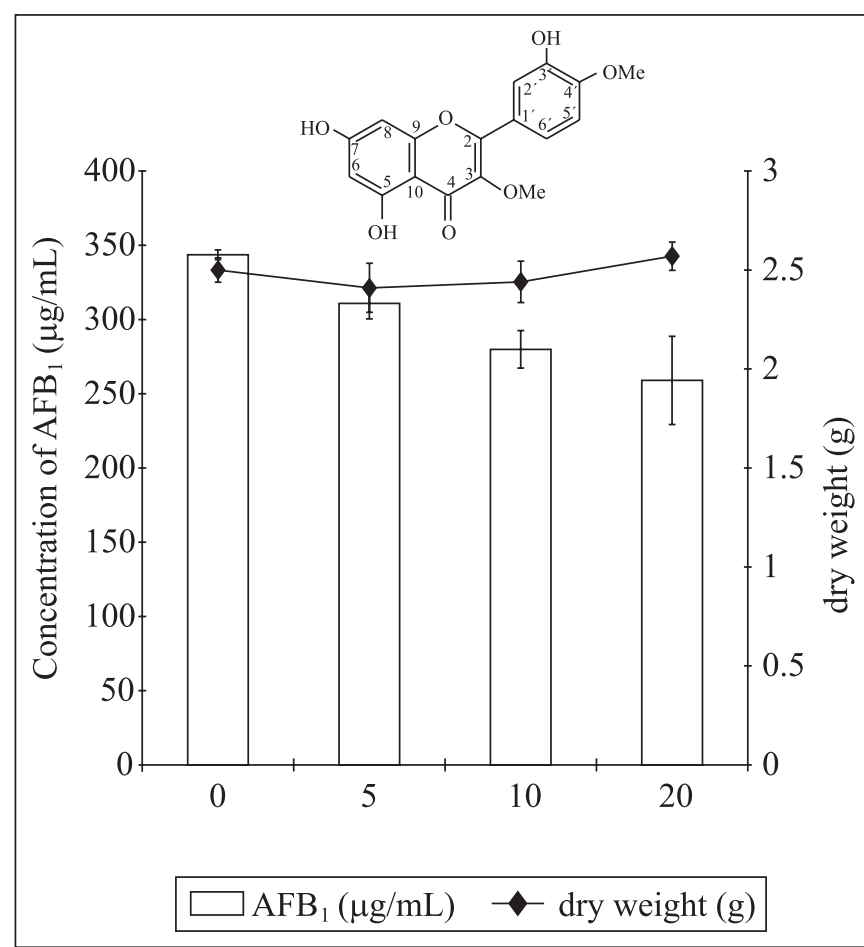

Figure 1. Production of aflatoxin $B_{1}$ and dry weight of Aspergillus flavus mycelium (IMI 190) in YES medium containing increasing concentrations (control, 5, 10 and $20 \mu \mathrm{g} / \mathrm{mL}$ ) of 3', 5, 7 trihydroxy-3, 4'-dimethoxyflavone (compound 1). The results correspond to mean \pm S.D.

( $p>0.05)$, in the concentrations tested. However, neither compounds showed a statisticaly significant level of inhibition of the fungal growth ( $>0.05)$ (Figs. 1 and 2).

The Compound 4 (enhydrin + uvedalin) has inhibited both the $\mathrm{AFB}_{1}$ production and fungus growth in a concentrationdependent manner (Fig. 4). On the other hand, in the concentrations tested (Fig. 3), enhydrin (compound 3) did not show a statistically significative inhibition activity $(\mathrm{p}>0.05)$ on $\mathrm{AFB}_{1}$ production and fungal growth.

\section{DISCUSSION}

In previous investigations $(1,7,10,11,13)$, very encouraging results were obtained on inhibition of aflatoxin production or fungal growth by flavonoids and sesquiterpene lactones. Compounds 3 and 4 were already isolated from leaves of $P$. sonchifolia by Inoue et al., 1995, but compounds 1 and 2 are described for the first time as constituents of this plant.

Inoue et al., 1995, reported that enhydrin showed lower fungicidal activity against Pyricularia oryzae than uvedalin. This result was attributed to the 4,5 epoxide group in enhydrin. The authors observed that activity of enhydrin against $A$. flavus,

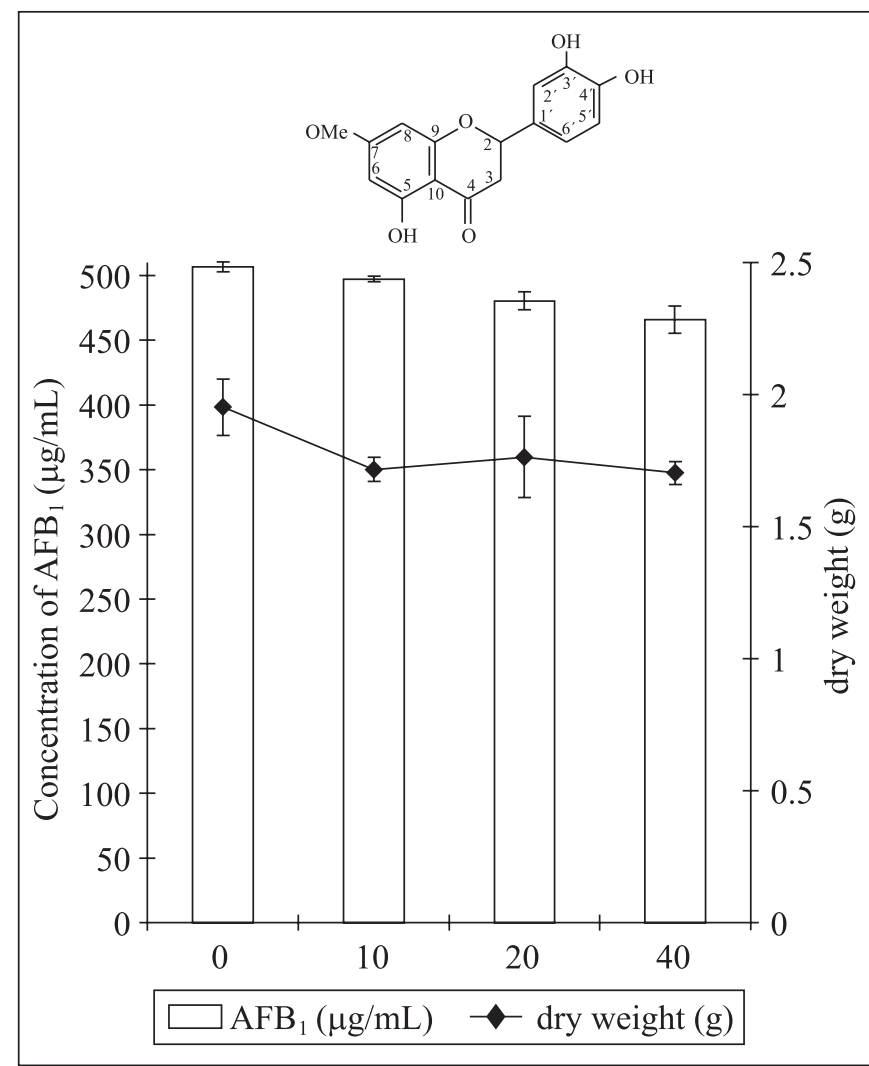

Figure 2. Production of aflatoxin $B_{1}$ and dry weight of Aspergillus flavus mycelium (IMI 190) in YES medium containing increasing concentrations (control, 10, 20 and $40 \mu \mathrm{g} / \mathrm{mL}$ ) of 3',4',5 - trihidroxi-7-metoxi-flavanone (compound 2). The results correspond to mean \pm S.D.

was low inhibiting only $8 \%$ of aflatoxin $\mathrm{B}_{1}$ production and $20 \%$ of fungal growth at $14 \mu \mathrm{g} / \mathrm{mL}$ concentration. This effect was not statistically significant $(\mathrm{p}>0.05)$, but it was concentration dependent (Fig. 3). However, compound 4, a mixture of enhydrin and uvedalin, showed the highest inhibitory action on aflatoxin $\mathrm{B}_{1}$ production in the tested concentrations. These results could caused by uvedalin only or by the synergic effect of the lactones mixture. The percentages of fungal growth inhibition and AFB1 production were $34 \%$ and $76 \%$, respectively, and showed statistical significance $(\mathrm{p}<0.05)$.

Some flavonoids and biflavonoids are biologically active against $A$. flavus and $A$. parasiticus $(7,10,11)$. In this work, two active flavonoids were isolated from $P$. sonchifolia leaves. Compound 1 inhibited $25 \%$ of the aflatoxin $\mathrm{B}_{1}$ production at the concentration of $15 \mu \mathrm{g} / \mathrm{mL}$ (p<0.01) (Fig. 1), and the compound 2 inhibited $8 \%$ of the aflatoxin $\mathrm{B}_{1}$ production $(\mathrm{p}>0.05)$ (Fig. 2$)$. The chemical analyses of compound 1 showed a higher oxidation pattern than compound 2 , and the oxidation pattern of the flavonoids and their position could be responsible by $\mathrm{AFB}_{1}$ 


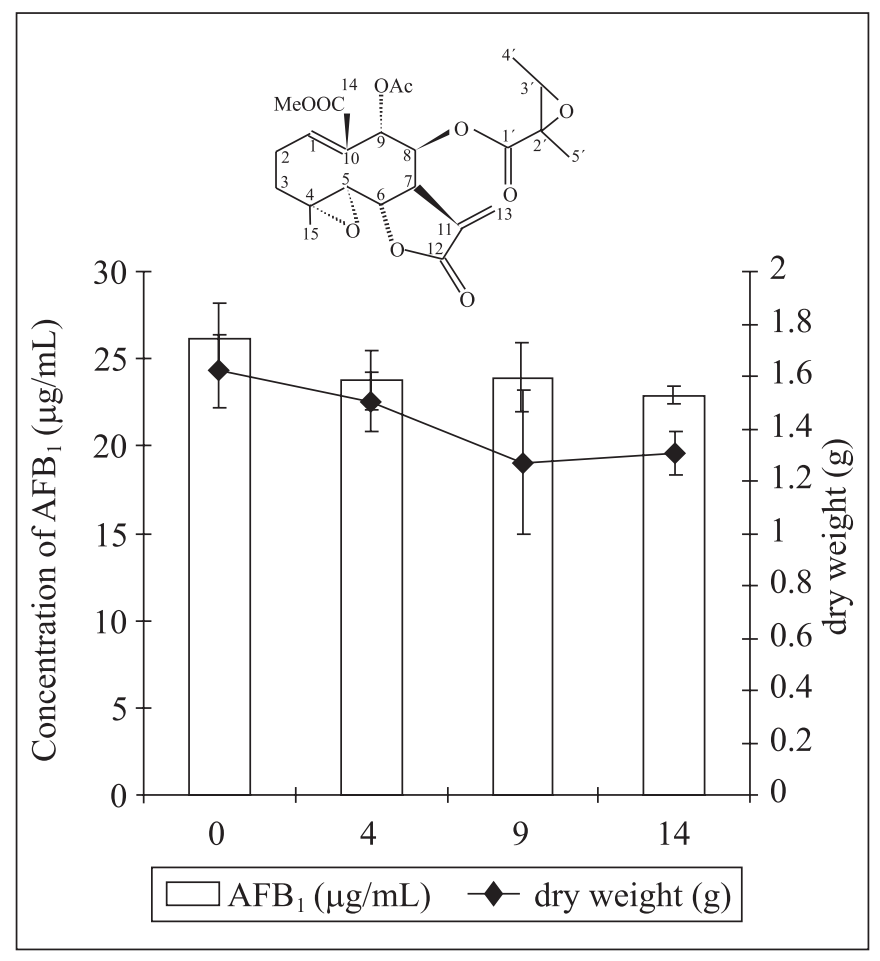

Figure 3. Production of aflatoxin $\mathrm{B}_{1}$ and dry weight of mycelium Aspergillus flavus (IMI 190) in YES medium containing increasing concentrations (control, 4, 9 and $14 \mu \mathrm{g} / \mathrm{mL}$ ) of enhydrin (compound 3). The results correspond to mean \pm S.D.

production inhibition $(7,10)$. Norton, 1999, reported that highest $\mathrm{AFB}_{1}$ inhibition was obtained with 3-OH compounds, which were three times more active than the related 3-deoxy compounds. Likewise, the 3-methoxyl in the ring $\mathrm{C}$ of the compound 1 can explain its higher activity than compound 2 (Figs. 1 and 2).

Compound 1 was not able to inhibit the fungal growth, while compound 2 inhibited $13 \%$ of the fungal growth at concentration $40 \mu \mathrm{g} / \mathrm{mL}$ (Figs. 1 and 2). Weidenborner et al, 1989, (17) observed that hydroxyl groups contribute to the higher polarity of the molecule which minimize the fungal membrane permeability of the substance in the same Aspergillus species. Therefore, several hydroxyl groups in the molecule are not conducive to antifungical activity. Our results agreed with literature, because compound 1 has higher oxidation pattern than compound 2 .

In conclusion, Polymnia sonchifolia is a promising plant that can be used in the control of aflatoxin $\mathrm{B}_{1}$ production by Aspergillus flavus.

\section{ACKNOWLEDGEMENTS}

The authors are grateful to the Fundação de Amparo à Pesquisa do Estado de São Paulo (FAPESP) for supporting the research, and to the Conselho Nacional de Desenvolvimento

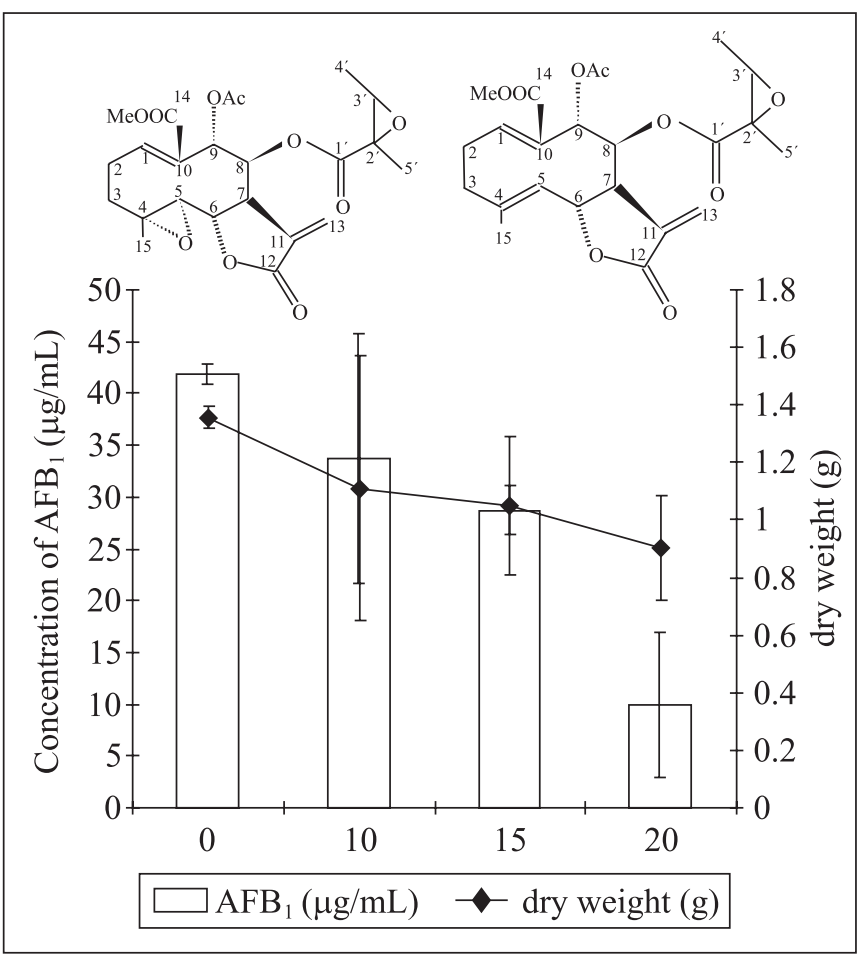

Figure 4. Production of aflatoxin $\mathrm{B}_{1}$ and dry weight of mycelium Aspergillus flavus (IMI 190) in YES medium containing increasing concentrations (control, 10, 15 and $20 \mu \mathrm{g} / \mathrm{mL}$ ) of mixture enhydrin and uvedalin (compound 4). The results correspond to mean \pm S.D.

Científico e Tecnológico (PIBIC-CNPq) for the grant to Marina M. Pinto.

\section{RESUMO}

\section{Produção de aflatoxina por Aspergillus flavus é inibida por compostos isolados de Polymnia sonchifolia}

Polymnia sonchifolia, conhecida como "Yacon", é originária da cordilheira dos Andes, sendo muito conhecida devido ao uso de seu tubérculo no controle da Diabetes melitus. Suas folhas podem conter compostos com atividade antifúngica e pesticida, pois não é necessário o uso destes produtos no seu cultivo. Neste trabalho descrevemos a identificação da estrutura química de dois flavonóides isolados das folhas de Polymnia sonchifolia: 3', 5, 7 trihydroxy-3, 4'-dimethoxyflavone (composto 1) e $3^{\prime}, 4^{\prime}, 5$-trihidroxi-7-metoxiflavanona (composto 2) e de duas lactonas sesquiterpenicas: enidrina (composto 3 ) e uma mistura de enidrina e uvedalina (composto 4), bem como seus efeitos na produção de aflatoxinas por Aspergillus flavus. A identificação dos compostos foi realizada por $\mathrm{RMN}{ }^{13} \mathrm{C}$ e ${ }^{1} \mathrm{H}$. 
Todos os compostos foram testados em diversas concentrações em cultura de Aspergillus flavus para avaliar o crescimento e a produção de aflatoxina. $\mathrm{O}$ composto 1 na concentração de 15 $\mu \mathrm{g} / \mathrm{mL}$ inibiu $25 \%$ da produção de aflatoxina $\mathrm{B}_{1}(\mathrm{p}<0,01)$. O composto 4 inibiu o crescimento do fungo e a produção da aflatoxina $\mathrm{B}_{1}$ em $34 \%$ e $76 \%$, respectivamente. Os resultados mostraram a possibilidade do uso de Polymnia sonchifolia no controle alternativo da produção de aflatoxina $\mathrm{B}_{1}$ pelo fungo Aspergillus flavus.

Palavras-chave: Polymnia sonchifolia, flavonóides, melampolideos, aflatoxinas, Aspergillus flavus

\section{REFERENCES}

1. Bullerman, L.B.; Lieu F.Y.; Seief, S.A. Inhibition of growth and aflatoxin production by cinnamon and clove oils. Cinnamic aldehyde and eugenol. J. Food Sci., 42, 1107-1109, 1977.

2. Coulombe, R.A. Aflatoxin. In: R.P. Sharma and DK Salunkhe (Eds.), Mycotoxins and Phytoalexins, CRC Press, London, 103-144, 1991.

3. Davis, N.D.; Diener, U.L.; Eldridge, D.W. Production of aflatoxins B1 and G1 by Aspergillus flavus in semisynthetic medium. Appl. Microbiol., 14, 378-380, 1966.

4. Dutton, M.F.; Anderson, M.S. Inhibition of aflatoxin biosynthesis by organophosphorus compounds. J. Food Prot., 43, 381-384, 1980.

5. Fan, J.J.; Chen, J.H. Inhibition of aflatoxin-production fungi by welsh onion extracts. J. Food Prot., 62, 414-417, 1999.

6. Gonçalez, E.; Felicio, J.D.; Pinto, M.M.; Rossi, M.H.; Medina, C.; Fernandes, M.J.B.; Simoni, I. C. Inhibition of aflatoxin production by Polymnia sonchifolia and its in vitro cytotoxicity. Arq. Inst. Biol., 70(2), 159-163, 2003.
7. Gonçalez, E.; Felicio, J.D.; Pinto, M.M. Biflavonoids inhibit the production aflatoxin by Aspergillus flavus. Braz. J. Med. Biol. Res., 34, 1453-1456, 2001.

8. International Agency for Research on Cancer (IARC). Aflatoxins: Natural occurring aflatoxinas (Group 1), aflatoxin $\mathrm{M}_{1}$ (Group 2B). Lyon: IARC Scientific Publications, no. 56, 1993, 245p.

9. Inoue, A.; Tamogami, S.; Kato, H., Nakazato, Y., Akiyama, M.; Kodama, O.; Akatsuka, T.; Hashidoko, .Antifungical melampolides from leaf extracts of Smallanthus sonchifolius. Phytochemistry, 39, 845-848, 1995

10. Mallozzi, M.A.B.; Corrêa, B.; Haraguchi, M.; Brignani, F.N. Effect of flavonoids on Aspergillus flavus growth and aflatoxin production. Rev. Microbiol., 27, 161-167, 1996.

11. Norton, R.A. Inhibition of aflatoxin B1 biosynthesis in Aspergillus flavus by anthocyanidins and related flavonoids. J. Agric. Food Chem., 47, 1230-1235, 1999.

12. Pinto, M.M.; Gonçalez, E.; Rossi, M.H.; Felicio, J.D.; Medina, C.S.; Fernandes, M.J. B.; Simoni I.C. Activity of the aqueous extract from Polymnia sonchifolia leaves on growth and production of aflatoxin B1 by Aspergillus flavus. Braz. J. Microbiol., 32, 127-129, 2001.

13. Sobolev, V.S.; Cole, J.R.; Dorner, J.W. Isolation, purification, and liquid chromatographic determination of stilbene phytoalexins in penauts. J. AOAC Int., 78, 1177-1182, 1995.

14. Steinhart, C.E.; Doyle, M.E.; Cochrane, B.A. Mycotoxins. In: C.E. Steinhart, M.E. Doyle, B.A. Cochrane (Eds), Food safety, Marcel Dekker, New York, 376-394, 1996.

15. Stoloff, L. Aflatoxin as a cause of primary liver-cell cancer in the United States: a probability study. Nutr. Cancer, 5, 165-186, 1983.

16. Sydenham, E.W.; Gelderblom, W.C.A.; Thiel, P.G.; Marasas, W.F.O. Evidence for the natural occurrence of fumonisin $\mathrm{B}_{1}$, a mycotoxin produced by Fusarium verticillioides in corn. J. Agric. Food Chem., 38, 285-290, 1990

17. Weidenborner, M.; Hindorf, H.; Jha, H.C.; Tsontsonos, P.; Egge, H. Antifungal activity of isoflavonoids against storage fungi of the genus Aspergillus. Phytochemistry, 28(12), 3317-3319, 1989. 